\title{
MEANINGS AND SIGNIFICANCE OF COLONIAL ARCHITECTURE IN DOUALA, CAMEROON
}

\author{
ZOURMBA OUSMANOU \\ University of Genoa, Italy
}

\begin{abstract}
The concept of heritage has experienced expanding meanings that link it to history, memories, tourism and business products, to name just a few of them. The heritagization process of architectural sites enlightened and focused most of the time, on aesthetical, know-how and the memory of the use of the site. Therefore, architectural heritage is not necessarily focusing on dynamics of memories surrounding it and might be limited to celebrating engineers and architects. In this regard, could it be worth referring to colonial architecture in Africa as heritage sites? To what extent could an architecture that celebrates former oppressors become a heritage site? What cultural or historical significance can colonial built remains convey to the African communities on whose territory they are located? This contribution, in light of the topic of heritage architecture and historical aspects, seeks to discuss the interaction between colonial memories and the enhancement of colonial built remains as historical/cultural heritage.
\end{abstract}

Keywords: colonial architecture, colonial heritage, dissonant heritage.

\section{INTRODUCTION}

The interest in the preservation of the architectural heritage, like the industrial heritage, is born from the desire to preserve an expression of the genius of the architect, as well as that of the reuse of space. For a long time, studies of cultural heritage enhancement have focused on, among other things, artistic objects such as paintings, sculptures, precious objects found during archaeological excavations. These objects are thus exhibited in museums, limiting culture to a kind of world collection [1]. The successive economic crises in Europe have left industrial ruins, including both machines and buildings. These crises raised the issue of the preservation of the history and the memories of many industrial sites.

In the African context, particularly in Douala, Cameroon, the European colonial presence has marked the collective memories through the relations that have developed between the so-called indigenous populations and the Europeans, through the social, political, economic and cultural changes induced by the colonial presence. The city of Douala, thanks to its geographical position, is the epicenter of all colonial enterprises in Cameroon, be it the European penetration, resistance movements to colonial occupation, struggles for independence. Douala thus constitutes a good summary of the colonial history of Cameroon. That colonial history could shortly be summarized as follows: from 1884 to 1916, German protectorate period, followed in 1916, by the occupation of the allied armies, which imposed a form of administration called condominium. From 1919, Cameroon came under the Mandate of the League of Nations (SDN), then the United Nations Trusteeship from 1945 on. The separate independences of the country began in 1960 with French Cameroon and ended in 1961 by the independence of the British Cameroon.

The accession to independence was accompanied by a particular concern to the Western powers at the time, linked to the preservation of their heritage. The architectural legacy in particular raises the problem of urban planning. By introducing a new architectural model for the construction of residences and administrative offices, by setting up transportation infrastructures such as railways, railway stations and car and locomotive maintenance spaces, by creating cutting-edge trading spaces with the open-air markets that were most 
prevalent in Africa until the 19th century, colonization created, accidentally or not, new cities and reinforced pre-colonial cities [2], as Goerg points out: "s'il est évident que la colonisation n'importe pas la ville en Afrique, on peut toutefois énoncer que la majorité des Africains accèdent à la ville via la ville coloniale et que, dans la dynamique de longue durée qui marque le continent, le moment colonial de la ville est un temps fort de l'urbanisation" [3]. Yet it is this African city, of colonial footprint that is rejected as the entire colonial system. To which extend can the legacy of former oppressor constitutes a heritage for his victim? Could it be worth referring to colonial architecture in Africa as heritage sites? What cultural or historical significance can colonial built remains convey to the African communities on whose territory they are located?

Beyond questioning the heritage value of colonial buildings, these questions bring up to date the ideas that have led to the implementation of colonial infrastructure projects, including urban plans. The reflection, based on historiography, sources of various archives and observation, will present the colonial architecture in Douala as an architecture of experimentation, an architecture symbol of the power of colonial domination, and an architecture with stakes of memories and history.

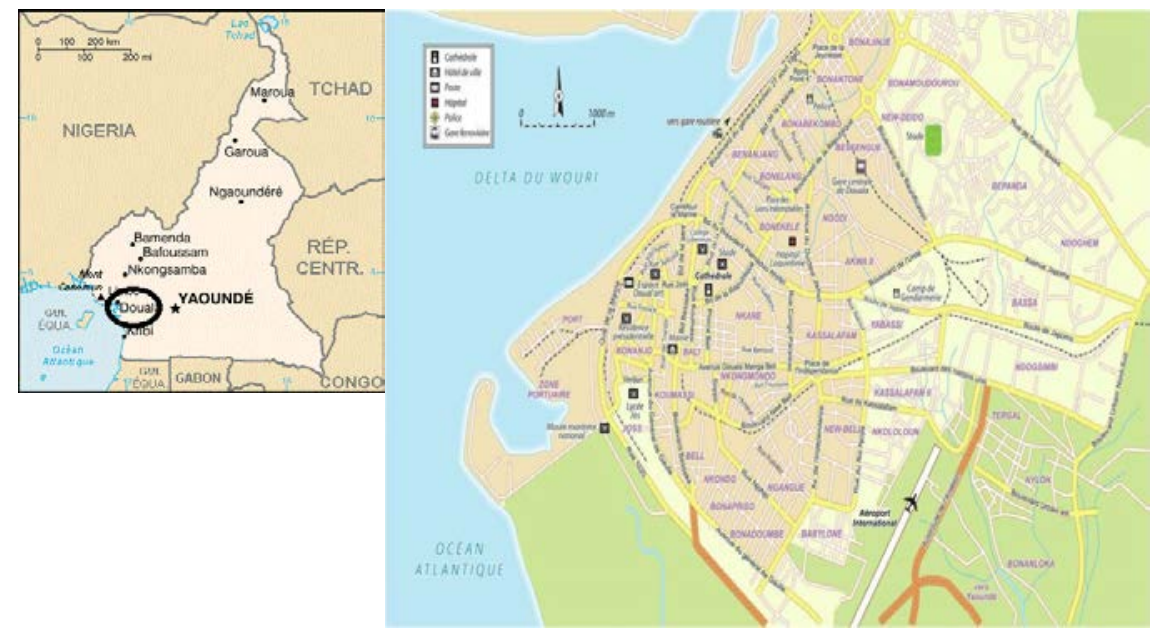

Figure 1: Map of the city of Douala [4].

\section{AN EXPERIMENTAL ARCHITECTURE}

To understand the value and quality of the colonial buildings in Douala, it is necessary to start from the vision and the legal framework surrounding their construction. The beginnings of western (German) colonization in Cameroon were made of clear idea and vision of their presence. Arrived, thanks to trade agreements, the Germans, until February 1885, did not consider to settle permanently in Cameroon. Their idea, intertwining the racism that prevails in the Germanic literature and philosophy that symbolize in particular authors like Hegel, was to exploit the economic resources, to develop the commerce, while keeping some distance from the local populations [5]. Some explorers recommended not teaching German language to Cameroonians and to interact with them in pidgin, a language issued from a misuse of English. In the same way, when the French took possession of the colony, their first idea was to erase all traces of the German presence, both intangible and physical. Although these positions have significantly shifted, it remains that they have had 
consequences, especially in the construction of colonial infrastructures. Thus, they lead to an experimental architecture on the one hand, and on the other hand, were more functionalist rather than aesthetic constructions.

Indeed, the architectural expression of the European powers in colonial Cameroon took place in an environment as difficult from a technical point of view as it was deliberately experimental. The arrival of European colonizers has come up against a major challenge, that of the difference in human environments, with an architectural type that does not obey western modernity. In Douala, most of the houses had straw roofs, with a rectangular shape. Some rare houses were inspired from European architecture thanks to the contacts made with British merchants [6].

In addition, the construction of buildings on the model of modernist architecture faced a serious challenge of materials. Local people had until then learned the use of the brick only thanks to missionaries who first arrived in Douala in the late 1840s. Moreover, the latter did not have a well-developed expertise in the field, to back an infrastructure project as desired by the Germans as part of their various urban plans. They acquired employees as slaves from Togo, with a promise to grant them freedom after some achievements. A revolt within the police troops, which resulted in the burning of its seat, led the Germans to abandon the track of Togolese employees, who had a better control of certain buildings. Beyond the constraints of work force, the transportation of equipment was also another challenge for infrastructure projects. Douala was certainly already a port city, but the port did not allow docking large boats. In order to control the trade, the Duala chiefs divided the Wouri coast in pieces of land under their strict control. The port operated in such a way that merchant ships used to parking in the middle of the river and are loaded and unloaded by small canoes. This constitutes a real limit to the transport of material types of construction.

Taking advantage of these constraints in addition to the absence of a fixed plan of urbanization as well as legislation governing the work of architects, the implementation of infrastructure projects served as a pretext for experiments, as Eloundou claims: "Les architectes et ingénieurs ont souvent travaillé avec une plus grande liberté, dans un contexte géographique et administratif où la règlementation était moins stricte" [7]. In most cases, architects who have worked in colonial Africa are not renowned architects or engineers. Therefore, by the types of colonial buildings, one can estimate that largely, it is an architecture of experimentation. Examples prove it in Douala, especially the hospital known as European's hospital.

In the particular case of the European's hospital in Douala, the evolution of the building attests of the experimental character of its architecture. Initiated by Dr. Albert Plehn, the hospital was built in 1896, with Henri Drees as project manager. This first pavilion, comprising 16 rooms in $\mathrm{R}+1$ form, measured $42 \mathrm{~m}$. Building much admired in its time, including by the German administrators, a second segment of the same architecture reinforced it. After the departure of the Germans, France gives it its current look, adding a third building in 1930, still respecting the original architecture [8]. Lack of elements of archives do not allow presenting architectural plans of that building. Following pictures give nevertheless an idea of the building.

The evolution of this building highlights that the architects were more guided by its functionality, the need to have a health center rather than to achieve a particular aesthetic architectural prowess. It must be remembered that when the Germans arrived in Douala, one of the problems they had to face fiercely was health. Some people felt that local people did not know the basic rules of hygiene. They believe that this promotes the emergence of diseases, to the point of imagining a clear separation of the living environments of Europeans and local populations. 


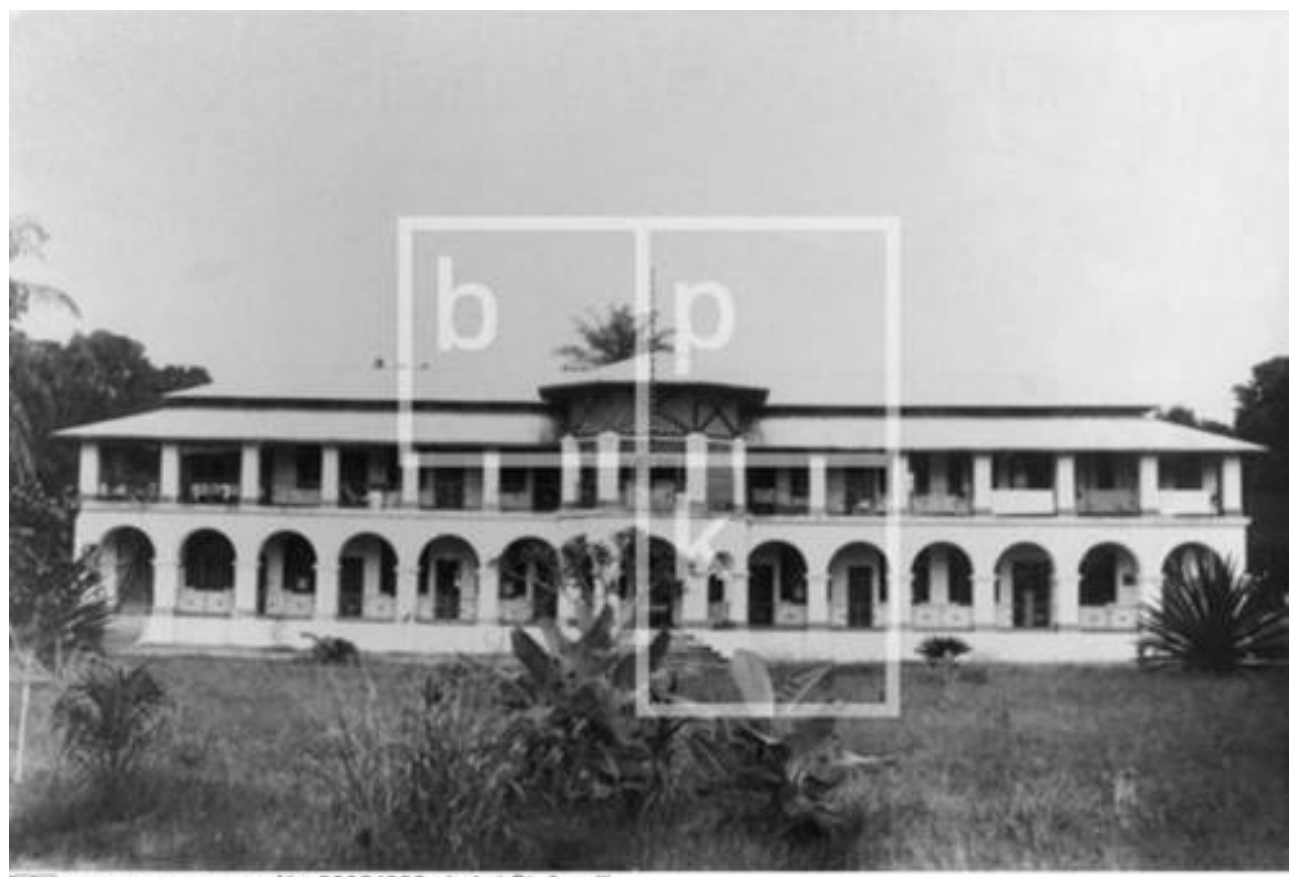

GP bildarchiv preussischer No. 30024986, bpk / Stefenell

6 Vulturbesitz Regierungshospital for WeiBe

Figure 2: First building of the European's hospital in Douala, 1902 [9].

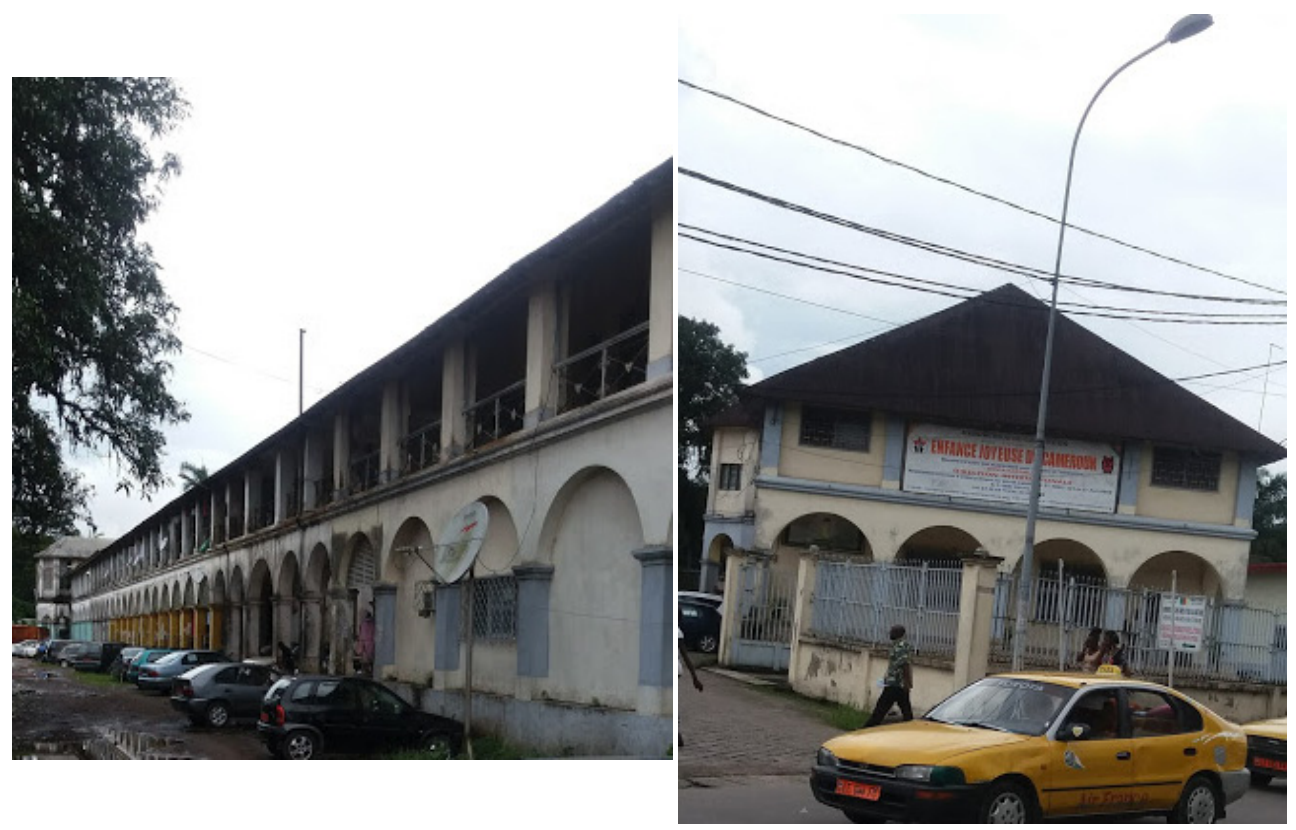

Figure 3: Current views of the European's hospital. (Source: Author, 18 May 2018.) 


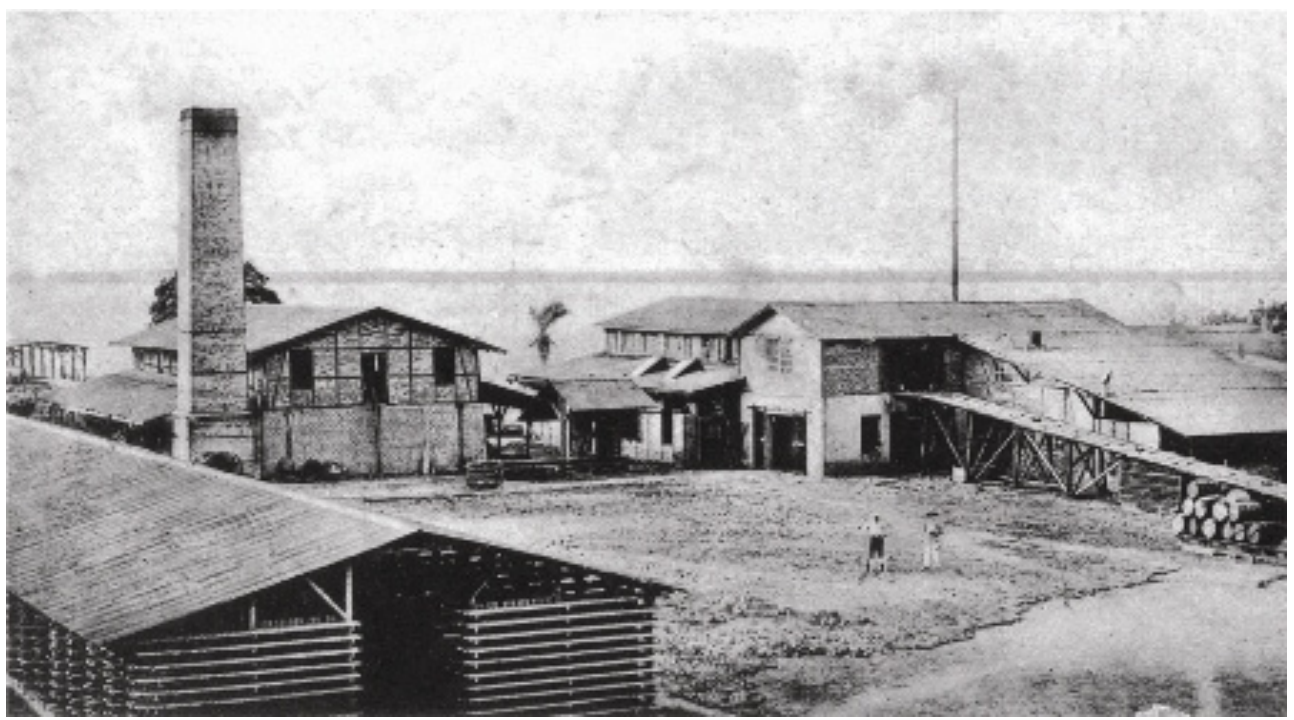

Figure 4: German water treatment complex [10].

Such examples of buildings whose utility outweighs the aesthetics or the seductive dimension of their design, are multiple across the city of Douala.

This complex is built with temporary material, including wood and clay. All indications are that the project of its construction did not provide for a definitive implantation. The same remark is valid for the building of the Régie des Chemins de fer, which is another testimony of the absence of an inspiration or the aesthetic insufficiency of some colonial buildings in Douala. Therefore, it seems wrong to summarize the colonial architecture in Africa to a modernist architecture.

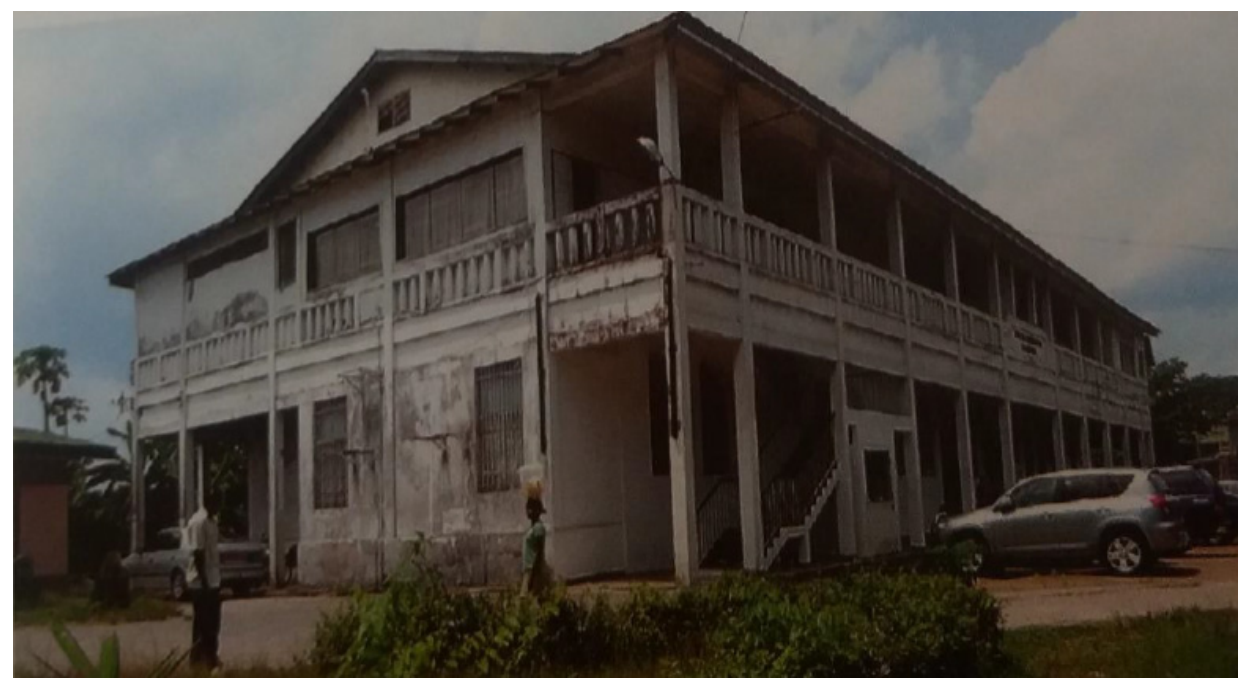

Figure 5: Building of the Régie des Chemins de fer du Cameroun in the 1930s [11, p. 17]. 


\section{AN ARCHITECTURE SYMBOL OF POWER AND DOMINATION}

The buildings of the colonial administration in Douala are among the most resistant vestiges of the time, perhaps because of the continuity of their use for public services, but also their architectural quality. In most cases, these are solid and futuristic buildings, built in a sharp approach with the bare minimum mentioned above. This is true both in the German and French periods.

One of the relevant examples of buildings that symbolize the European domination and power is the First Government Headquarters, built in 1891. It has an $\mathrm{R}+1$ structure, and covered with a sheet metal roof. Some authors argue that this is the period the majority of buildings in Douala were made of fair quality material. Germans decided to import modern building material from Hamburg as some authors point out: "la majorité du bâti était constituée de petites maisons en torchis et toitures végétales comme le montrent les photographies anciennes. Soucieux de s'inscrire dans la durée, ils (Germans) élèvent pendant la première quinzaine d'années, des édifices en utilisant des matériaux importés de Hambourg, bois, briques et ciment, structures métalliques pour le gros œuvre, tôles et tuiles pour les toitures" [11].

Beyond the material for its construction, the headquarters of the first government of colonial Cameroon symbolizes the power of Germany. Its structure is similar to most of the buildings of German royalties in its European and African territories. One of its best short description is from Hervé-Brice Nguembou: "L'édifice reposait sur un socle d'un mètre de haut, les murs étaient en briques, les planchers en planches 'Metlasch' importés. Les plafonds étaient en tôle ondulée posée sur des solives métalliques et recouverte d'une couche de ciment. Le toit enfin était en bois recouvert de carton bitumé. L'aile principale comportait onze pièces".

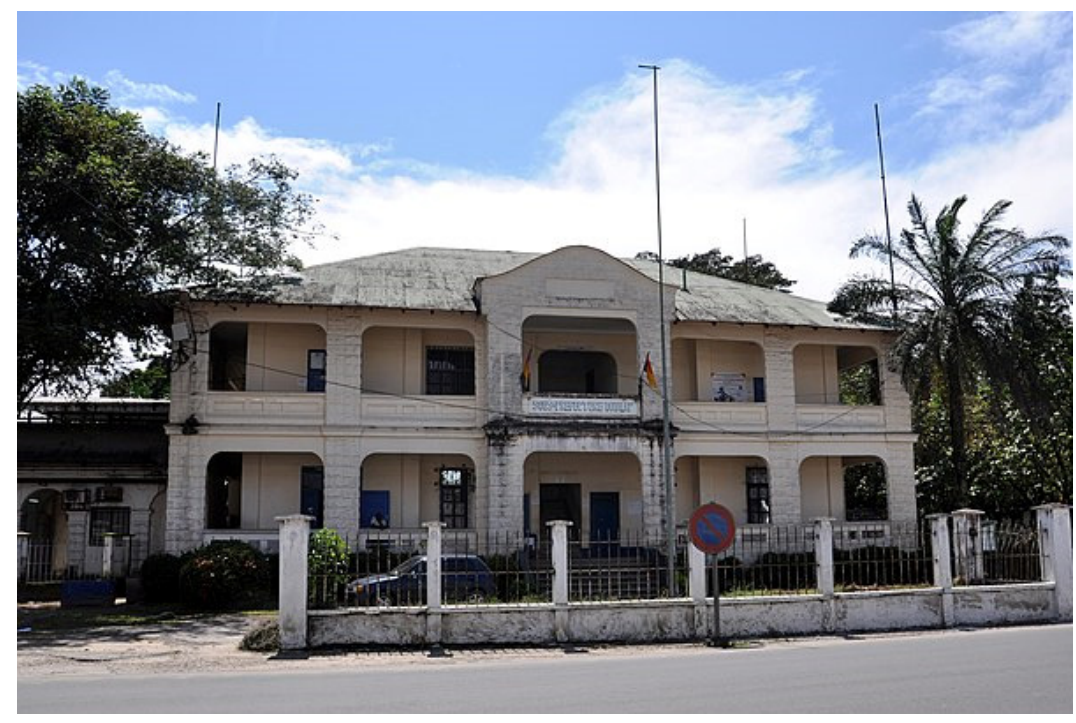

Figure 6: Government Headquarters in Douala [12].

Another important building is that of the Head of Douala District's residence under French Mandate and Trusteeship. In the administrative organization of Cameroon under the French Mandate, Douala was a Head of District. This induces the existence of offices and 
residences for the officials. Built in 1930 in the "art deco" style, this building was renowned for its beauty: "Le bâtiment se rattache au style 'art deco' par ses volumes, sa tour d'angle et son ornamentation végétale et géométrique en façade". Nonetheless, few archives exist to afford it with further description, as it is the case for many of the buildings.

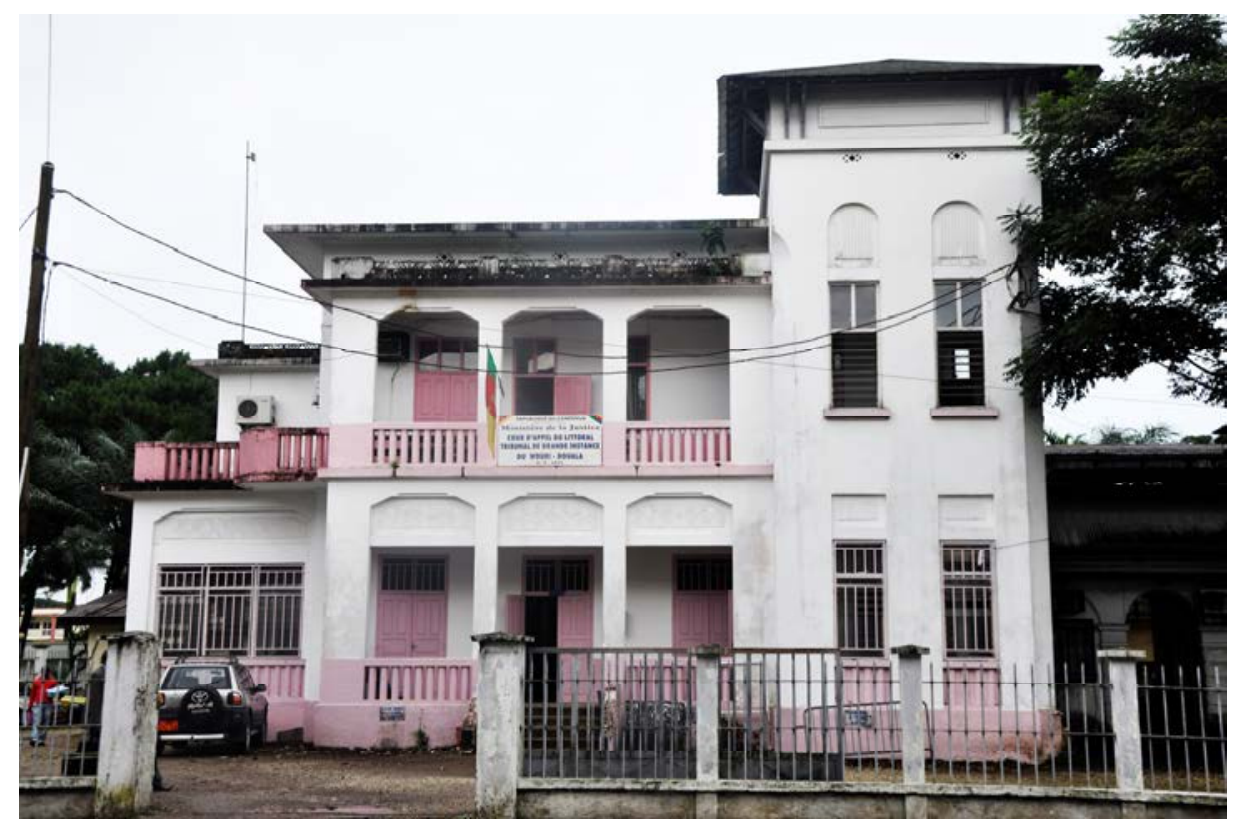

Figure 7: Douala District Head's residence [13].

These two examples support the idea that through architecture, Germany and France expressed their power in Cameroon. This power is the main source of hard memories connected to some buildings.

The building of the former German police is one of colonial remains with a rich history, with hard and educative side. The police units in fact, inaugurated the military colonial presence of Germany in Cameroon. As mentioned above, after the signature of the protectorate's agreements in Douala, Germans hesitated to settle down an administrative system, under the control of their central Government. Along with the decision of making Cameroon a colony, Von Gravenreuth created the Polizeitruppe Kamerun in 1889. In 1893, he reinforced the troop with 370 slaves bought from Dahomey (western Africa). The condition for these slaves to acquire their freedom was to achieve five years' service for the benefit of the German colonial master [14]. However, things went wrong with these foreign police troops, because of cruel treatments. A mutiny lead to the death of their commander and the destruction of their headquarters in Douala. No picture of that first building has yet been found. The one currently in use by the Merchant Navy replaced the first ever. It is built in bricks, respecting the German royal architecture. Yet for many people in Douala, the building remember hard periods of struggle against Germans, beginning with the time they decided expropriation. It should be noted that these struggles lead to the sentence to death of Duala Manga Bell, a famous king in Douala. 


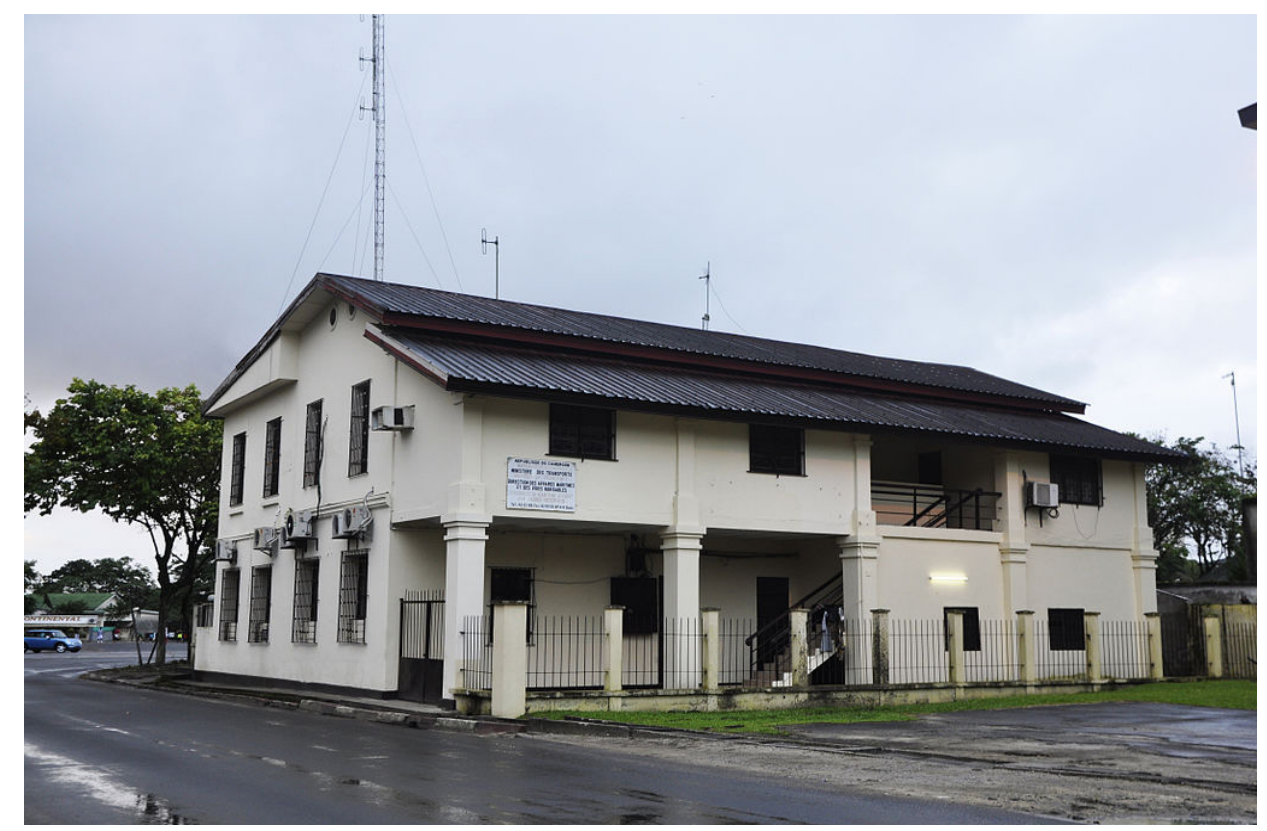

Figure 8: German Police Headquarters in Douala [15].

\section{CONCLUSIONS}

The colonial built remains in Douala are first and foremost, testimonies of history, memorial places. It should be emphasized that in the African context, beyond written sources, the restitution of history is relied on oral, iconographic and material evidence among others. In the case of the history of Cameroon in general and the city of Douala in particular, archives of the German protectorate disappeared during the First World War. This explains the lack of information on most of buildings above mentioned. Nevertheless, these buildings alone bear important testimonies of the colonial past, but also symbolize collective memories.

Talking of colonial buildings in Douala, for a good part of the local population up to the present days, is referring to difficult times related to the implementation of the German urbanization plans, with their corollaries expropriation and conviction. Most of the administrative buildings of the colonial era were erected on a coveted space, the mechanism of eviction and expropriation. One of the urban plans that created a misunderstanding between the German and the Duala people is the 1906 plan, which provided for the creation of a European city on the site of the Canton Bell. The latter were forced to retreat from the banks of the Wouri, to occupy current neighborhoods of Bonapriso and Bali. In addition, the urban plans of the French administration have devoted the essential framework of German projects, as well as the emerging quarter of New-Bell, lacking infrastructures and rules of settlement. When the Bells decided to oppose the expropriations, the response of the German administrators was the death sentence of their leader Duala Manga. Since then, the buildings, which sheltered the security forces and the colonial administrations in Douala, recall this painful period.

In addition, remains of colonial infrastructure and colonial trading companies in Douala symbolize the memories of forced labor, lashing, the difficult portage system and 
exploitation of all kinds that characterize colonial systems in Africa. In general, during the German period, forced labor was imposed on all adults, but especially men, with a view to the construction of infrastructures, as well as for punishing locals who disrespect colonial rules. They required every Cameroonian to submit a work card, on which at least 20 hours of service per month should be mentioned by a contractor or construction manager of German nationality. Which means that every Cameroonian had to work 20 hours a month in the service of Germany. In the absence of such mention, the person implicated is punished with torture, including 25 public lashes. Moreover, the workforce has been overexploited on various sites. For example, in the construction of the railway, the work equipment was essentially manual; the difficulties of transporting large machines that did not allow the use of advanced technology on construction sites.

To sum up, the colonial built remains in Douala represent stakes of memory and history. They are a testimony, tangible traces of the colonial past in Cameroon. They thus represent a heritage value that must be separated from the ideological rejection of colonial systems.

\section{REFERENCES}

[1] Owona Nguini, M.-E., Penser le patrimoine à partir de N.M. Granel: une reflecture géopolitique d' "à chacun son patrimoine", 15, pp. 3-5, 2003.

[2] Coquery-Vidrovitch, C., Villes coloniales et histoire des Africains, Vingtième Siècle. Revue d'Histoire, 20, pp. 49-73, 1988.

[3] Georg, O., Domination coloniale et construction de la "ville" en Afrique et dénomination. Afrique et Histoire, 1, pp. 15-45, 2006.

[4] Découvrir et aimer le Cameroun, Cartes des régions du Cameroun et plans. www.editions2015.com/cameroun/cartes.php. Accessed on: 13 Dec. 2015.

[5] Pasarge, S., Adamawa: Rapport de l'expédition du Comité allemand pour le Cameroun au cours des années 1893-1894, Karthala: Paris, 2010.

[6] Soulillou, J., Douala, un siècle en images, l'Harmattan: Paris, 2018.

[7] Eloundou, L., Le patrimoine architectural moderne en contexte africain. Proceedings of the Conference Repenser les limites: l'architecture à travers l'espace, le temps et les disciplines, INHA, Paris, 2005. http://inha.revues.org/902. Accessed on: 2 Feb. 2018.

[8] Nguembou, H.-B., Une histoire des monuments de la ville de Douala. Douala, histoire et patrimoine, eds E. Tchumtchoua \& A.F. Dikoume, Editions CLE: Yaoundé, pp. 357-380, 2014.

[9] La Grande Guerre au Cameroun, Photos du Kamerun allemand (avant 1914). $\mathrm{http}$ //pedagogie.lyceesaviodouala.org/histoire-geographie/app_grandeguerre/pages/page_6a.htm. Accessed on: 20 Apr. 2018.

[10] Doual'art, Cheminée de Bonakouamouang. http://doualart.org/spip.php?article170. Accessed on: 26 Apr. 2016.

[11] Houvounsadi, J. et al., Douala capitale économique: l'architecture, Lieux dits, 2011.

[12] WikiVividly, Former general hospital of Douala. https://wikivividly.com/wiki/ Former_general_Hospital_of_Douala. Accessed on: 16 Apr. 2018.

[13] https://upload.wikimedia.org/wikipedia/commons/8/87/ANCIEN_RESIDENCE_DU CHEF_DE_CIRCONSCRIPTION.JPG. Accessed on: 18 Apr. 2018.

[14] De Quesada, A. \& Dale, C., Imperial German Colonial and Overseas Troops 18851918, Osprey Publishing, 2014.

[15] Wiki, Ancien commissariat de police de Douala. https://www.know.cf/enciclopedia/ FR/Ancien_commissariat_de_police_de_Douala. Accessed on: 26 Mar. 2018. 